\title{
BEHAVIOUR OF MODERATELY DIFFERENTIATED OSTEOBLAST-LIKE CELLS CULTURED IN CONTACT WITH BIOACTIVE GLASSES
}

\author{
S. Hattar, A. Berdal, A. Asselin, S. Loty, D.C. Greenspan and J-M Sautier*
}

Laboratoire de Biologie Orofaciale et Pathologie, INSERM EMI-U 0110, Université Paris 7, UFR d'Odontologie, Institut Biomédical des Cordeliers, Esc. E - 2è étage, 15-21 rue de l'Ecole de Médecine, F-75270 Paris Cedex 06, France.

\begin{abstract}
Bioactive glasses have been shown to stimulate osteogenesis both in vivo and in vitro. However, the molecular mechanisms underlying this process are still poorly understood. In this study, we have investigated the behaviour of osteoblast-like cells (MG63), cultured in the presence of bioglass particles. Three types of granules were used: $45 \mathrm{~S} 5^{\circledR}$ bioactive glass, $45 \mathrm{~S} 5^{\circledR}$ granules preincubated in tris buffer and 60S non-reactive glass, used as control. Phase contrast microscopy permitted step-by-step visualization of cell cultures in contact with the particles. Ultrastructural observations of undecalcified sections revealed direct contacts of the cells and an electron-dense layer located at the periphery of the material. Protein synthesis was evaluated biochemically and showed a gradual increase throughout the culture time in the three types of cultures. Alkaline phosphatase was detected in situ, in clusters of packed cells either in contact with the material or in the background cell layer. Semi-quantitative RT-PCR analysis of the main osteoblastic markers showed that gene expression was maintained in all three cultures. The fact that osteocalcin was not detected, supports the fact that the MG63 cell line is composed of less differentiated osteogenic cells rather than mature osteoblasts. We also demonstrated for the first time in this cell line, the expression of Msx-2, Dlx-3 and Dlx-7 homeogenes, known to regulate in vivo foetal skeletogenesis as well as adult skeletal regeneration. However, no significant differences could be recognised in the expression pattern of bone markers between the three types of cultures. Yet these preliminary results indicate that bioactive glasses provided a suitable environment for the growth and proliferation of osteoblasts in vitro, since no drastic changes in phenotype expression of pre-osteoblasts was noted.
\end{abstract}

Key Words: Bioactive glasses, in vitro, MG63 cell line, Msx-2, Dlx-3, Cbfa-1.

*Address for correspondence:

Jean-Michel Sautier

Laboratoire de Biologie Orofaciale et Pathologie,

INSERM EMI-U 0110, Institut Biomédical des Cordeliers,

Esc. E - 2è étage, 15-21 rue de l'Ecole de Médecine

F-75270 Paris Cedex 06, France.

Telephone Number: 33(1) 43269496

Fax Number: 33(1) 44071421

E-mail: sautier@ccr.jussieu.fr

\section{Introduction}

In reconstructive surgery, the repair of large bone defects is a major problem. While the use of autografts has been the most widely recommended approach, it does have its drawbacks, including donor site morbidity, limited donor bone supply, as well as different anatomic and structural problems. Another alternative is the use allografts, but these have the disadvantage of eliciting an immunological response due to genetic differences, as well as the risk of inducing transmissible diseases. As a result, more attention has been directed towards the use of synthetic graft materials. During the last two decades, the development of new implant technologies have shifted from attempts to create passive interface between implant and tissue, to the design concept of bioactive materials. By definition, a bioactive material is "one that elicits a specific biological response at the interface of the material that results in the formation of a bond between the tissues and the material" (Hench et al., 1971). Within this interesting category, we find a wide range of calcium phosphate ceramics (Ca-P), bioactive glasses (BG) and bioactive glass-ceramics (Hench and West, 1996; Kokubo et al., 1990). All these materials possess the common characteristic of generating a carbonated hydroxyapatite layer that is equivalent chemically and structurally to the biological mineral of bone. This is known to be the determining step for the biointegration (Kitsugi et al., 1987; Ito et al., 1987; Hench and Paschall, 1973). Furthermore, several comparative studies have demonstrated the efficacy of bioglasses in stimulating cellular responses in comparison to other Ca-P ceramics such as the Hydroxyapatite (HA) (Oonishi et al., 1997; Vrouwenvelder et al., 1993; 1994). However, a very limited range of bioactive glass composition having less than $55 \% \mathrm{SiO}_{2}$ exhibit a high bioactive index, this range of materials exhibits not only osteoconductivity, but are responsible also of osteoproduction by stimulating proliferation and differentiation of osteprogenitor cells (Ohgushi et al., 1996).

These glasses have been widely used in a variety of clinical applications, from middle ear prosthetic ossicles in otological surgery (Reck et al., 1988) to bone grafting material in the fields of maxillofacial surgery (Kinnunen et al., 2000) and dentistry (Yukna et al., 2001; Allan et al., 2001; Park et al., 2001). Nevertheless, synthetic materials typically cannot replace all the functions of a host tissue and are incapable of adapting to the body's changing need overtime. Because of these limitations the search for new alternative strategies for repairing bone defects have been focused on tissue engineering. One of its approaches is the use of material matrices as tem- 
plates for tissue growth in vitro (Loty et al. 2001; ElGhannam et al., 1995; Ducheyne et al., 1994). Once again, bioactive glasses seem to find their place, for they fulfill most of the criteria required for a suitable scaffold to support bone tissue growth, since they are known to enhance proliferation and prevent de-differentiation of osteoblast in vitro (Price et al., 1997; El-Ghannam et al., 1997a,b; Vrouwenvelder et al., 1992; Matsuda and Davies, 1987).

A number of studies have shown that ionic products released from of bioactive glass dissolution, create a favorable environment for osteoblast proliferation and differentiation in vivo. However, this high bioactivity index could result in a rapid $\mathrm{pH}$ shift of the culture medium in vitro that may be unfavorable for cellular metabolism. Therefore, in an attempt to optimize in vitro desirable biological effects, different assays of surface conditioning have been performed prior to the seeding of cells (Xynos et al., 2000; Price et al., 1997; El-Ghannam et al., 1995; 1997a,b; Ducheyne et al., 1994). Although the osteogenic stimulatory effects of BG are well documented, the biological mechanisms that mediate these effects are still largely unknown. In this study, we have evaluated the effect of bioactive granules on moderately differentiated osteoblastlike cells. To achieve this goal, we have used the human osteoblast-like cell line MG63 as the cellular prototype (Billiau et al., 1975). This cell line, originally isolated from a human osteosarcoma, has been well characterized (Lajeunesse et al., 1990; 1991) and largely used in biocompatibility tests (Lohmann et al., 1999; Boyan et al., 1998; Lincks et al., 1998; Martin et al., 1995). In our study, we used either $45 \mathrm{~S} 5^{\text {â }} \mathrm{BG}$ granules, or 45S5 granules conditioned prior to the cultures, by incubation in tris buffer to generate the Ca-P surface layer. 60S nonreactive glass was used as control.

Here, we confirm that the three kinds of granules support the growth of moderately differentiated osteoblastlike cells. We also demonstrated for the first time in this cell line, the expression of Msx-2, Dlx-3 and Dlx-7 homeogenes, known to regulate in vivo fetal skeletogenesis but also adult skeletal regeneration. Furthermore, Msx-2 and Dlx-3-7 pattern expression was not altered by the presence of materials.

\section{Materials and Methods Material preparation}

Bioactive glasses melt-type Class A (45S5 Bioglass $\left.{ }^{\hat{a}}\right)$, were kindly provided by USBiomaterials Corporation (Alachua, FL, USA). The composition is (in weight $\%$ ): $45 \% \mathrm{SiO}_{2}$ $24.5 \% \mathrm{Na}_{2} \mathrm{O}, 24.5 \% \mathrm{CaO}$ and $6 \%$ of $\mathrm{P}_{2} \mathrm{O}_{5}$. BG were used in the form of 710-90 $\mu \mathrm{m}$ particles, as were the bio-inert 60s glass particles. In each experiment, three types of granules were used: $45 \mathrm{~S} 5$ bioactive granules (45S5), 45S5 'preconditioned' in a tris buffer, thus allowing the creation of a hydroxyapaptite superficial layer. This layer was formed subsequent to immersion of the 45S5 bioactive granules in a solution of tris (hydroxy)methylaminomethane (THAM) with a concentration of $0.2 \mathrm{M}$ [THAM: $\left.\mathrm{NH}_{2} \mathrm{C}\left(\mathrm{CH}_{2} \mathrm{OH}\right)_{3} \mathrm{pH}=7.25\right]$, for a period of 48 hours at $37^{\circ} \mathrm{C}$. Then the granules were rinsed in acetone and left to dry (45-Tris). The third substrate was $60 \mathrm{~S}$ glass (60S), known to be bioinert (Hench et al., 1971), served as the control in our experiments $(60 \mathrm{~S})$. All the granules were sterilized by dry heat at $180^{\circ} \mathrm{C}$ for 2 hours in a furnace, prior to the experiments.

\section{Cells and cell culture conditions}

MG63 osteoblast-like cells, originally isolated from a human osteosarcoma (Billiau et al., 1975), were used for these experiments. MG63 have been well characterized, and widely used for testing biomaterials. In order to limit differences in phenotypic expression, the cells were used at either passage 11 or 12 . The cells were grown in DMEM (Dulbecco's Modified Eagle Medium) supplemented with ascorbic acid $(50 \mu \mathrm{g} / \mathrm{ml}), 10 \mathrm{mM}$ B-glycerophosphate $\left(\right.$ Sigma $^{\circledR}$, St. Louis, MO, USA), 50 UI/ml Penicillin-Streptomycin $\left(\mathrm{Gibco}^{\circledR}\right.$, Paisley, UK) and 10\% fetal calf serum (FCS) (Abcys ${ }^{\circledR}$, Paris, France). The cells were maintained at $37^{\circ} \mathrm{C}$ in a fully humidified atmosphere at $5 \% \mathrm{CO}_{2}$ in air. The media was changed every 48 hours. After 3 days in culture, the cells were passaged with Trypsin-EDTA $\left(\right.$ Gibco $\left.^{\circledR}\right)$, counted on Malassez cells and plated at a density of $2.10^{4} \mathrm{cell} / \mathrm{cm}^{2}$ in $60-\mathrm{mm}$ petri dishes. BG granules were added (30mg/culture dish) to the wells, 24 hours later. While it was not possible to guarantee that the particles were evenly distributed in the well plates, the experiments were conducted in triplicate to minimize any gross errors caused by uneven distribution of the particles.

\section{Transmission electron microscopy}

The cells cultured with bioglass particles, were observed at day 5. First the cell cultures were washed three times in DMEM 0\% FCS, fixed in Karnovsky solution (4\% paraformaldehyde, $1 \%$ glutaraldehyde) for 1 hour. After several rinses in $0.2 \mathrm{M}$ sodium cacodylate buffer ( $\mathrm{pH} 7.4$ ), cell cultures were post-fixed for 1 hour in osmium tetroxide diluted in $0.2 \mathrm{M}$ sodium cacodylate buffer. The cells were then dehydrated in graded series of ethanol and left overnight in a mixture of absolute ethanol and epon (1:1). The next day the cells were embeded in Epon Araldite and incubated at $60^{\circ} \mathrm{C}$ for 1 day. Semithin sections were cut perpendicularly to the cell layers with a diamond knife and mounted on glass slides, stained with toluidine blue (Merck ${ }^{\circledR}$, Darmstadt, Germany) and examined under light microscopy for orientation purposes. Ultrathin sections were performed, collected on copper grids, and stained with $2.5 \%$ uranyl acetate in absolute ethanol for 4 minutes and lead citrate for 2 minutes. The sections were then examined under a Philips (Eindhoven, The Netherlands) CM-12 transmission electron microscope (TEM).

\section{Protein synthesis}

The protein assays (in triplicate) were established on days 3, 5, 7, 10 and 13. At each point, the cell cultures were washed 3 times with DMEM without FCS on ice, then with sodium carbonate-bicarbonate buffer $\left(\mathrm{NaHCO}_{3}\right.$ $\mathrm{Na}_{2} \mathrm{CO}_{3} 0.1 \mathrm{M} \mathrm{pH}=10.2$ ) and frozen at $-80^{\circ} \mathrm{C}$. At time of measurement, cells were unfrozen, incubated in an extraction buffer $(0.1 \mathrm{M}$ sodium carbonate bicarbonate, $\mathrm{pH}$ 
Table 1: Primers for MG63 mRNA Amplification

\begin{tabular}{|l|l|l|l|l|}
\hline mRNA & Frgmt & Primer 1 & Primer 2 & Tm \\
\hline Cbfa1 & $300 \mathrm{bp}$ & GGACGAGGCAAGAAGAGTTTCAC & TGCCTGCCTGGGATCTGTAA & $55^{\circ} \mathrm{C}$ \\
AP & $525 \mathrm{bp}$ & CATCTGGAACCGCACGGAAC & GCCTGGTAGTTGTTGTGAGC & $55^{\circ} \mathrm{C}$ \\
CO-I & $318 \mathrm{bp}$ & AAGATGTGCCACTCTGACTG & ATAGGTGATGTTCTGGGAGG & $55^{\circ} \mathrm{C}$ \\
BMP-4 & $420 \mathrm{bp}$ & CGAAGAACATCTGGAGAACA & CACTCCCTTGAGGTAACGAT & $55^{\circ} \mathrm{C}$ \\
Dlx 3 & $421 \mathrm{bp}$ & AAGGTCCGAAAGCCGCGTA & CTGCTGCTGTAAGTGGGGT & $55^{\circ} \mathrm{C}$ \\
Dlx 7 & $297 \mathrm{pb}$ & TGAAACTGTCCGTCCTACCC & GGAGCGTTTGTTCTGAAACC & $52^{\circ} \mathrm{C}$ \\
Msx2 & $240 \mathrm{bp}$ & CCTCGGTCAAGTCGGAAAATT & TGAGGTTCAGAGAGCTGGAGAA & $58^{\circ} \mathrm{C}$ \\
GAPDH & $401 \mathrm{bp}$ & GACCCCTTCATTGACCTCAACTAC & AAGTTGTCATGGATGACCTTGGCC & $55^{\circ} \mathrm{C}$ \\
\hline
\end{tabular}

10.2, $\mathrm{MgCl}_{2} 1 \mathrm{mM}, 0.2 \%$ Nonidet NP40) for $10 \mathrm{~min}$ and removed from the substrate with a rubber policeman. The extracts were sonicated $(3 \times 20 \mathrm{sec})$ on ice, before protein assay to dissociate extracellular matrix.

Estimation of protein content was carried out using the Pierce BCA Protein Assay Kit (Pierce Chemicals, Dallas, TX, USA). This method used a reactive solution of bicinchoninic acid (BCA) and $\mathrm{CuSO}_{4} \cdot \mathrm{Cu}^{2+}$ ions were reduced by proteins of the cell suspension into $\mathrm{Cu}^{+}$ions, which formed a complex with BCA. The crimson coloration of this complex was directly proportional to the protein concentration and the absorption read in a spectrophotometer (Beckman 25) at 562nm.

\section{Extraction of RNA and RT-PCR amplification}

Total RNA was extracted at day 2, 4, 6, 9 and 15, using a phenol/chloroform method (Tri reagent, Euromedex ${ }^{\circledR}$, Souffelweyersheim, France. At the appropriate day, the cells were washed 3 times with PBS $1 X$ on ice; then $1 \mathrm{ml}$ of reagent was added to each culture dish. Total RNA was then precipitated with isopropanol and centrifuged at $15000 \mathrm{~g}$ at $4^{\circ} \mathrm{C}$. The RNA pellet was washed with $75 \%$ ethanol and resuspended in RNase free water. The concentration and the purity of total RNA in each sample were determined by light absorbance at $260 \mathrm{~nm}$ and by calculating the $A_{260} / A_{280}$ ratio, respectively. RNA integrity was confirmed by electrophoresis on an agarose/ ethidium bromide gel. The gel showed three predominant ribosomal RNA bands $28 \mathrm{~S}, 18 \mathrm{~S}$ and $5 \mathrm{~S}$. Gene expression was analyzed by RT-PCR. Reverse transcription reactions were carried out for each RNA sample using "cDNA Cycle ${ }^{\circledR} "$ (Invitrogen, San Diego, CA, USA), according to manufacturer's protocol. Each reaction tube contained $2 \mu \mathrm{g}$ of total RNA in a total volume of $20 \mu \mathrm{l}$ containing RT Buffer, $0.01 \mu \mathrm{g} / \mu \mathrm{l}$ oligo dT Primer, $0.5 \mathrm{U} /$ $\mu 1$ RNase Inhibitor, 5mM dNTP's, 4mM sodium pyrophosphate, $0.25 \mathrm{U} / \mu 1$ AMV Reverse Transcriptase. RT reaction was incubated at $42^{\circ} \mathrm{C}$ for $60 \mathrm{~min}$ and terminated by heat inactivating the reverse transcriptase, and denaturing the RNA-cDNA hybrids at $95^{\circ} \mathrm{C}$ for $2 \mathrm{~min}$.

The resulting cDNA $(2 \mu \mathrm{l})$ of each sample, were first heated to $94^{\circ} \mathrm{C}$ for $5 \mathrm{~min}$ in a final volume of $50 \mu 1$, containing tris buffer, $2 \mathrm{mM} \mathrm{MgCl}, 2 \mathrm{mM}$ dNTP, $0.03 \mathrm{U} / \mu 1$ Eurobio (Les Ulis, France) Taq DNA polymerase, and 0.2 $\mu \mathrm{M}$ of forward and reverse primers for each gene (see Table 1 for primer sequences). The samples were then amplified for 35 cycles of $30 \mathrm{sec}$ at $94^{\circ} \mathrm{C}, 30 \mathrm{sec}$ at Tm, and 40-50 sec (elongation time depending on the amplified fragment) at $72^{\circ} \mathrm{C}$. A final heating step was carried out at $72^{\circ} \mathrm{C}$ for $7 \mathrm{~min}$, all in a thermal cycler (Perkin Elmer Gene Amp ${ }^{\circledR}$ PCR System 2400) (Perkin-Elmer, Wellesley, MA, USA). To control false positive results, RT-PCR reactions were performed in a separate area of the laboratory with equipment other than that used for product analysis. In addition, control reactions without added RT products were performed in parallel with these reactions.

Aliquots (10-35 $\mu 1)$ of amplified cDNA were electrophoresed on a $2 \%$ agarose gel containing ethidium bromide. The gel showed a single band at the appropriate level, when the mRNA was expressed.

\section{Cytoenzymatic localization of alkaline phosphatase}

Cultured cells were fixed in situ, at different times at room temperature in $2 \%$ Citrate-Acetone solution for 30 s. Cultures were then washed in sterile water for $45 \mathrm{~s}$. The cells were exposed for $30 \mathrm{~min}$ to a solution containing naphthol-phosphate as a substrate and Fast Blue Salt RR as a coupler (Sigma), at room temperature and in the dark. The cultures were washed with water and observed without counter staining. As a control, cultures were incubated in the absence of substrate.

\section{Results}

\section{Cultures with Bioglass granules}

The MG63 cells were trypsinized and seeded at a density of $2.10^{4} \mathrm{cell} / \mathrm{cm}^{2}$ in the presence of vitamin $\mathrm{C}$ and b-glycerophosphate. Phase contrast microscopy showed that 2 hours later, the cells started to attach and spread on the culture dishes, exhibiting a polygonal morphology (data not shown). The next day, the material granules were added to the cultures (45S5, 45S5-Tris and 60S granules).

Possessing a high rate of cell division, the cells proliferated and reached confluence by day 2 of culture, immobilizing the granules in the cell layer (Fig. 1A). Thereafter, the cells piled up around the granules forming refrin- 

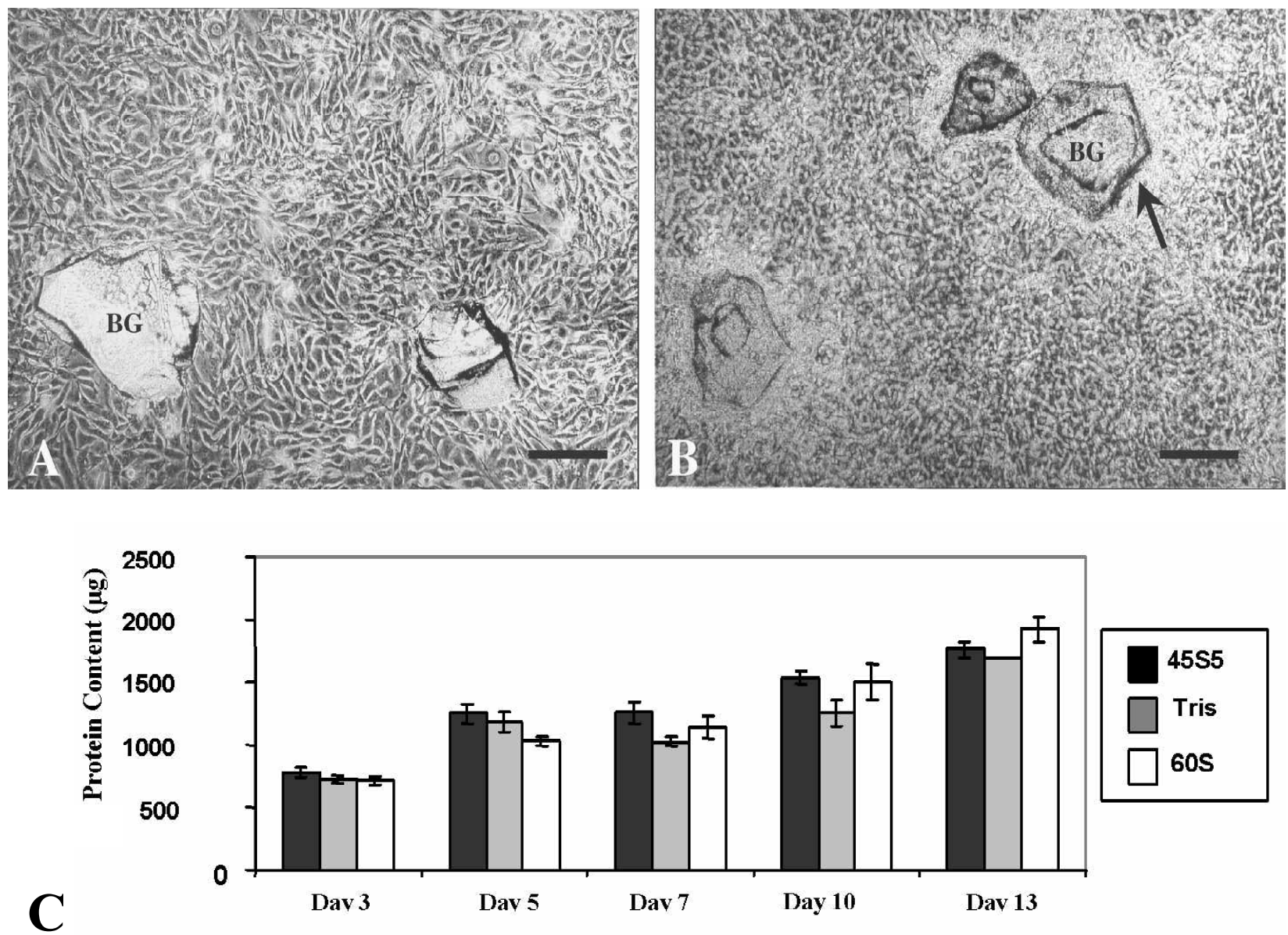

Figure 1. Phase contrast microscopic observations, showing MG63 cell proliferation around 45S5 BG granules at different times: Scale bar $=500 \mu \mathrm{m}$. (A) day 2, cells proliferated and reached confluency. (B) day 11, cells are arranged in multilayers, and formed a refringent matrix (arrow) around the granules. BG: bioactive 45S5 granules. (C) Histogram showing the time course of protein synthesis in MG63 cell cultures. 45S5: bioactive granules, 45-Tris: granules preincubated in tris buffer, $60 \mathrm{~S}$ control cultures.

gent multilayers (Fig. 1B). At further time points in the experiments, the cells did not show any evidence of advanced osteoblast differentiation. Furthermore, during this period, no significant morphological differences between the three types of cultures were noted. In addition, protein synthesis slowly increased during the culture period, as determined biochemically, but with no significant differences between the three types of cultures (Fig. 1C).

On day 5 of culture, transmission electron microscopy (TEM) confirmed the previous observations showing multilayers of cells around BG particles (Fig. 2A). These cells had large nuclei with occasional chromatin masses. Undecalcified sections produced a break-down of the material, but we can observe an electron dense layer, that correspond to the periphery of the granules and where cell contacts can be seen (Fig. 2B and 2C). At a higher magnification, we can clearly see the dense band, surrounding the granules, composed of needle shaped crystals (Fig. 2C). In addition, multiple intercellular contacts were observed and the extracellular matrix was poor in collagen fibers (Fig. 2D).

Cytoenzymatic localization of alkaline phosphatase was not detectable until day 7 (fig. 3A-B). The positive staining is visible in clusters of cells either in contact or apart from the granules. No obvious differences were observed between the different types of culture.

\section{Expression of osteoblast-related mRNA}

Osteoblast morphogenetic and phenotypic markers were analyzed from day 2 up to day 15 of culture by semi-quantitative RT-PCR (Fig.4): type-I collagen (Coll-I), alkaline phosphatase (AP), core-binding factor 1(Cbfa1), muscle segment homeobox 2 (Msx2), distal-less homeobox 3-7 (Dlx3-7), and bone morphogenetic protein-4 (BMP$4)$. The results showed that osteoblasts cultured in contact with 45S5, 45S5-Tris and 60s granules express all the studied markers but with some differences. In addition, a small amount of Cbfal was detected in all three cultures, however this expression seemed to become more important in cultures with 45S5 granules at day 15 .

\section{Discussion}

A line of evidence suggests that bioactive glasses can increase bone formation, however little is known on the 



Figure 2. Transmission electron microscopy of MG63 cells in contact with 45S5 BG granules at day 5. (A) cells exhibited large nuclei with occasional chromatin masses: Scale bar $=1 \mu \mathrm{m}$. (B) an electron dense layer (arrows) is located at the periphery of the granules: Scale bar $=1 \mu \mathrm{m}$. (C) higher magnification, the dense band is formed of an inner granular part and an outer part formed of needle shaped crystals (arrow): Scale bar $=1 \mu \mathrm{m}$. (D) cells showing multiple cell contacts (arrows): Scale bar $=1 \mu \mathrm{m}$. HA: Hydroxyapatite layer. OB: osteoblasts

cellular and molecular events underlying this effect. The aim of our study was to evaluate the effect of $45 \mathrm{~S} 5^{\text {a }}$ Bioglass on the growth and differentiation of the human moderately differentiated osteoblast-like cells. To achieve this goal we cultivated a human cell line (MG63) in the presence of BG granules for a period of 15 days. A series of morphological observations and gene expression analysis served this purpose. Our second goal was to investigate the expression pattern of Msx-2, Dlx-3 and Dlx-7 homeogenes and the master gene of skeletal cell differentiation, Cbfa-1.

The MG63 cell line has been well characterized showing numerous osteoblastic features, including the expression of BMP (Virdi et al., 1998), alkaline phosphatase (Boyan et al., 1998; Lincks et al., 1998), Cbfa-1 (SasakiIwaoka et al., 1999) as well as osteocalcin (Lajeunesse et al., 1990; Kue et al., 1999). However, in agreement with Boyan et al. (2002), we have failed to detect the production of osteocalcin or alkaline phosphatase, even after stimulation by either Vitamin D or dexamethazone (data not shown). In fact, the MG63 cell line we have used in this study is composed of immature cells that can be useful in studying the early cellular events that occurr in vivo when a biomaterial is implanted in a bony site. Indeed, the first bone cells that came in contact with an implanted material are probably osteoprogenitor cells rather than mature osteoblasts.

One interesting outcome of recent research has been the discovery that the genetic pathways controlling adult skeletal tissue were similar to the genetic pathways regulating fetal skeletal development (Ferguson et al., 1999). For these reasons, we have analyzed the expression pattern of a master gene of skeletal cell differentiation, and homeogenes known to control bone morphogenesis. We have shown that MG63 cells express Cbfa1, the earliest known transcription regulator of osteoblast differentiation and consequently demonstrated the commitment of these cells toward the osteogenic pathway. It has been revealed that the expression of Cbfal, a master gene of skeletal cell differentiation, is a key step in osteogenesis, as bone formation is totally blocked when its gene is ablated (Komori et al., 1997). In our culture conditions, 

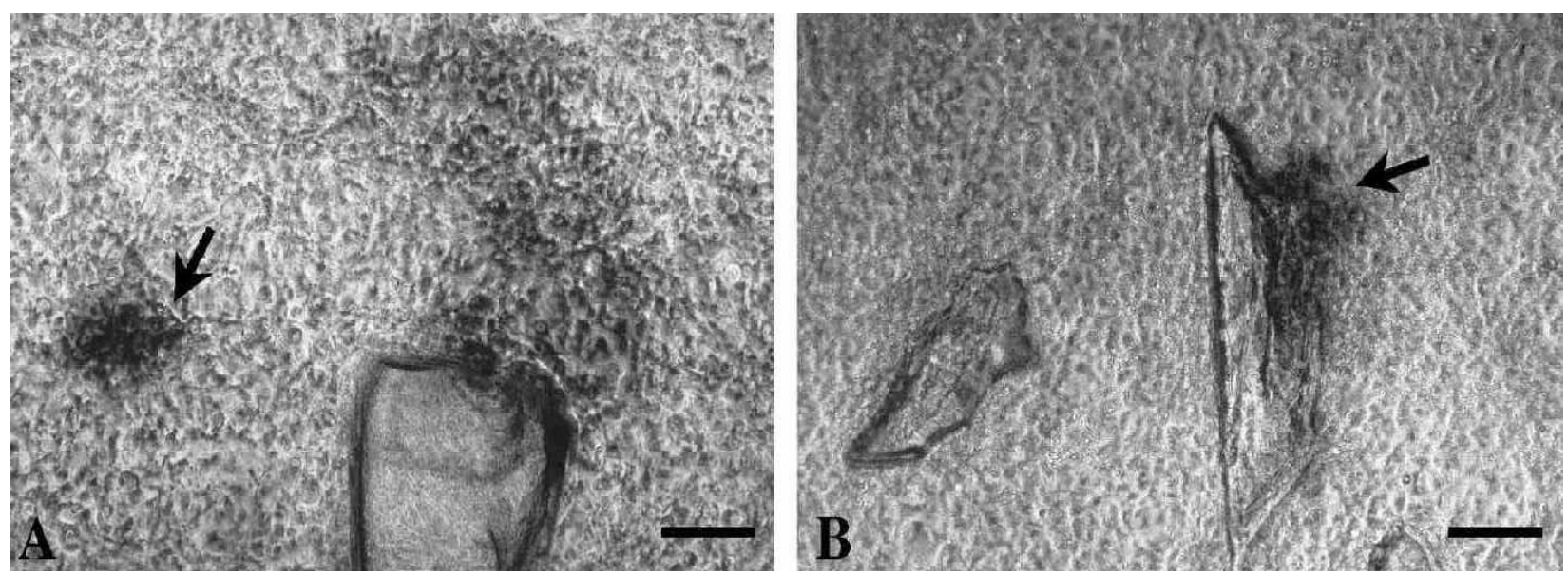

Figure 3. Cytoenzymatic localization of alkaline phosphatase on day 7: Scale bar $=500 \mu \mathrm{m}$. (A) Noted a positive reaction (arrow) in clustered cells. (B) A positive staining is also showed on cells in contact with bioactive granules (arrow).

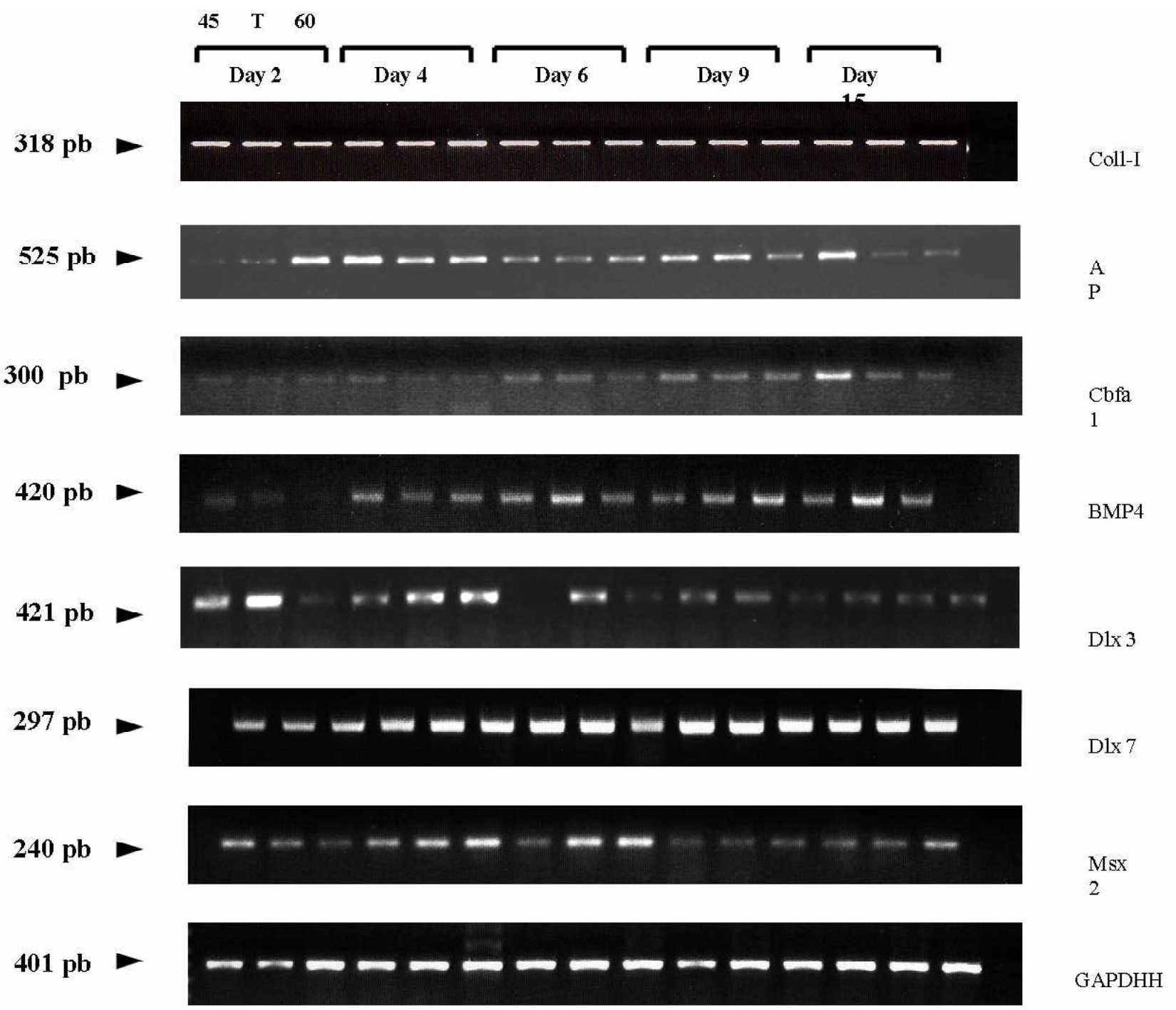

Figure 4. Analysis of mRNA temporal expression of osteoblast related genes in MG63 cells, cultured in contact with 45S5 BG, 45S5-Tris and 60s granules by RT-PCR techniques. The RT-PCR products were stained with ethidium bromide and visualized by UV irradiation. 
MG63 cells probably would need effectors (e.g. BMP) to fully express the osteoblast phenotype and express osteocalcin, a late osteoblast differentiation marker.

Numerous studies demonstrated a positive effect of bioactive glasses on attachment, proliferation, differentiation and mineralization of bone cells compared to nonreactive surfaces (Vrouwenvelder et al. 1992; Loty et al., 2001). However, in our study, no significant differences in the mRNA expression were found. While a slight increase in the expression of Cbfal was noted in cultures of $45 \mathrm{~S} 5$ at day 15 , we cannot conclude that bioactive glasses up-regulate mRNA expression. We have shown for the first time that the MG63 cell line expresses Msx-2, Dlx-3, Dlx-7 and that their expression was not altered by the presence of biomaterials. Msx-2 and Dlx-3 are homeodomain proteins that play an important role during embryonic skeletal formation. In our study, homeogene Msx-2 gradually decreased with time. This result is in agreement with the works of Liu et al., 1999 and Ryoo et al., 1997 that showed that Msx-2 was expressed during the proliferative phase of mouse osteoblastic cells and its expression level decreased with terminal osteoblastic differentiation. Furthermore, the overexpression of Msx 2 was shown to prevent osteoblast differentiation (Liu et al., 1999; Dodig et al., 1999). These results suggested that Msx-2 prevents terminal differentiation while promoting osteoprogenitor cells proliferation. A possible explanation on the arrest of terminal differentiation of MG63 cells could be an imbalance between the expression of endogeneous Msx-2 sense and anti-sense mRNA. For instance, an Msx-1 antisense mRNA was recently discovered in mice, rats and humans (Blin-Wakkach et al., 2001) as well as for Dlx-1 and Dlx-6 (Liu et al., 1997).

Fetal skeletal development and adult skeletal repair share a number of common characteristics. Recent advances in our understanding of the molecular regulation strongly suggested that the genetic mechanisms regulating fetal skeletogenesis also regulate adult skeletal regeneration and point to important regulators of bone regeneration (Ferguson et al., 1999). Finally, Msx-2 and Dlx-3 could be morphogenetic regulators, controlling bone formation and providing a guide to the early events in osteogenic differentiation.

Although the released-ionic products of bioglass dissolution create a favorable environment for osteoblast proliferation and differentiation in vivo, this high bioactivity index results in vitro, in a rapid $\mathrm{pH}$ shift of the culture medium that could be unfavorable for cellular metabolism (El Ghannam et al., 1997a; 1995). Based on this idea, we have chosen to incubate some granules in a solution of tris buffer at $37^{\circ} \mathrm{C}$ for $24 \mathrm{hr}$, prior to culture in order to generate a surface apatite layer as previously showed by several groups (Radin et al., 1997; Greenspan et al., 1996; Filgueiras et al., 1993). The results of gene analysis by RT-PCR have showed that this treatment did not obviously change the mRNA expression.

In conclusion, we have shown that 45S5 Bioglass ${ }^{a}$ either preconditioned or not supported growth of the MG63 cell line and maintained their phenotype. To our knowledge this is the first time that Msx-2, Dlx-3 and Dlx7 were detected in the MG63 cell line. However, no signifi- cant differences could be recognized in the expression pattern of bone markers between the three types of cultures. Future studies using well differentiated osteoblastic cell lines or primary cultures and using quantitative techniques could complete this study and provide new insight on the mechanisms whereby these glasses function.

\section{Acknowledgements}

The authors are grateful to Martine Obœuf for TEM technical assistance and Emile Marie-Rose for secretarial assistance. We thank US Biomaterials Corporation for providing the glass samples.

\section{References}

Allan I, Newman H, Wilson M (2001) Antibacterial activity of particulate bioglass against supra and subgingival bacteria. Biomaterials 22: 1683-1687.

Billiau A, Cassiman JJ, Willems D, Verhelst M, Heremans H (1975) In vitro cultivation of human tumor tissues. Oncology 31: 257-272.

Blin-Wakkach C, Lezot F, Ghoul-Mazgar S, Hotton D, Monteiro S, Teillaud C, Pibouin L, Orestes-Cardoso S, Papagerakis P, Macdougall M, Robert B, Berdal A (2001) Endogeneous Msx1 antisense transcript: in vivo and in vitro evidences, structure, and potential involvement in skeleton development in mammals. Proc Natl Acad Sci U S A 98: 7336-7341.

Boyan BD, Batzer R, Kieswetter K, Liu Y, Cochran DL, Szmuckler-Moncler S, Dean DD, Schwartz Z (1998) Titanium surface roughness alters responsiveness of MG63 osteoblast- like cells to 1 alpha,25-(OH)2D3. J Biomed Mater Res 39: 77-85.

Boyan BD, Bonewald LF, Sylvia VL, Nemere I, Larsson D, Norman AW, Rosser J, Dean DD (2002) Evidence for distinct membrane receptors for 1 alpha,25$(\mathrm{OH})(2) \mathrm{D}(3)$ and 24R, 25- $(\mathrm{OH})(2) \mathrm{D}(3)$ in osteoblasts. Steroids 67: 235-246.

Dodig M, Tadic T, Kronenberg MS, Dacic S, Liu YH, Maxson R, Rowe DW, Lichtler AC (1999) Ectopic Msx2 overexpression inhibits and Msx2 antisense stimulates calvarial osteoblast differentiation. Dev Biol 209: 298307.

Ducheyne P, El-Ghannam A, Shapiro I (1994) Effect of bioactive glass templates on osteoblast proliferation and in vitro synthesis of bone-like tissue. J Cell Biochem 56: 162-167.

El-Ghannam A, Ducheyne P, Shapiro IM (1995) Bioactive material template for in vitro synthesis of bone. J Biomed Mater Res 29: 359-370.

El-Ghannam A, Ducheyne P, Shapiro IM (1997a) Formation of surface reaction products on bioactive glass and their effects on the expresssion of the osteoblastic phenotype and the deposition of mineralized extracellular matrix. Biomaterials 18: 295-303.

El-Ghannam A, Ducheyne P, Shapiro IM (1997b) Porous bioactive glass and hydroxyapatite ceramic affect 
bone cell function in vitro along different time lines. $\mathrm{J}$ Biomed Mater Res 36: 167-180.

Filgueiras MR, La Torre G, Hench LL (1993) Solution effects on the surface reactions of a bioactive glass. J Biomed Mater Res 27: 445-453.

Ferguson C, Alpern E, Miclau T, Helms JA (1999) Does adult fracture recapitulate embryonic skeletal formation? Mech Dev 87: 57-66.

Greenspan DC, Zhong JP, Lobel KD (1996) In vitro hydroxyapatite formation on bioactive glasses. In: Fifth World Biomaterials Congress. Vol.1. Toronto, Canada. p 6 (abstr).

Hench LL, Paschall HA (1973) Direct chemical bond of bioactive glass ceramic materials to bone and muscle. J Biomed Mater Res Symposium 7: 25-42.

Hench LL, West JK (1996) Biological applications of bioactive glasses. Life Chemistry Reports 13: 187-241.

Hench LL, Splinter RJ, Allen WC, Greenlee TK (1971) Bonding mechanism at the interface of ceramic prosthetic materials. Part 1. J Biomed Mater Res Symp 2: 117-141.

Ito G, Matsuda T, Inoue N, Kamegai T (1987) A histological comparison of the tissue interface of bioglass and silica glass. J Biomed Mater Res 21: 485-497.

Kinnunen I, Aitasalo K, Pollonen M, Varpula M (2000) Reconstruction of orbital floor fractures using bioactive glass. J Craniomaxillofac Surg 28: 229-234.

Kitsugi T, Nakamura T, Yamamura T, Kokubo T, Shibuya T, Takagi T (1987) SEM-EPMA observation of three types of apatite containing glass ceramics implanted in bone: the variance of a Ca-P rich layer. J Biomed Mater Res 21: 1255-1271.

Kokubo T, Ito S, Huang T, Huyashi T, Sakka S, Kitsugi T, Yamamuro (1990) Ca,P-rich layer formed on high strength bioactive glass ceramic A-W. J Biomed Mater Res 24: 331-343.

Komori T, Yagi H, Nomura S, Yamagushi A, Sasaki K, Degushi K, Shimizu Y, Bronson RT, Gao YH, Inada M, Sato M, Okamoto R, Kitamura Y, Yoshiki S, Kishimoto $\mathrm{T}$ (1997) Targeted disruption of Cbfal results in complete lack of bone formation owing to maturational arrest of osteoblasts. Cell 89: 755-764.

Kue R, Sohrabi A, Nagle D, Frondoza C, Hungerford D (1999) Enhanced proliferation and osteocalcin production by human osteoblast-like MG63 cells on silicon nitride ceramic discs. Biomaterials 20: 1195-1201.

Lajeunesse D, Frondoza C, Schoffield B, Sacktor B (1990) Osteocalcin secretion by the human osteosarcoma cell line MG63. J Bone Miner Res 5: 915-922.

Lajeunesse D, Kiebzak GM, Frondoza CG, Sacktor B (1991) Regulation of osteocalcin secretion by human primary bone cells and by the human osteosarcoma cell line MG-63. Bone and Mineral 14: 237-250.

Lincks J, Boyan BD, Blanchard CR, Lohmann CH, Liu Y, Cochran DL, Dean DD, Schwartz Z (1998) Response of MG63 osteoblast like cells to titanium and titanium alloy is dependent on surface roughness and composition. Biomaterials 19: 2219-2232.

Liu JK, Ghattas I, Liu S, Chen S, Rubenstein JL (1997) Dlx genes encode DNA-binding proteins that are expressed in an overlapping and sequential pattern during basal ganglia differentiation. Dev Dyn 210: $498-512$

Liu Yh, Tang Z, Kundu RK, Wu L, Luo W, Zhu D, Sangiorgi F, Snead ML, Maxson RE (1999) Msx2 gene dosage influences the number of proliferative osteogenic cells in gowth centers of the developing murine skull: possible mechanism for Msx2 mediated craniosynostosis in humans. Dev Biol 205: 260-274.

Lohmann C, Sagun R, Sylvia V, Cochran D, Dean D, Boyan B, Schwartz Z (1999) Surface roughness modulates the response of MG-63 osteoblast like cells to 1,25$(\mathrm{OH})_{2} \mathrm{D}_{3}$ through regulation of phospholipase $\mathrm{A}_{2}$ activity and activation of protein kinase A. J Biomed Mater Res 47: 139-151.

Loty C, Sautier JM, Tan MT, Oboeuf M, Jallot E, Boulekbache H, Greenspan D, Forest N (2001) Bioactive glass stimulates in vitro osteoblast differentiation and creates a favorable template for bone tissue formation. J Bone Miner Res 16: 231-239.

Martin JY, Schwartz Z, Hummert TW, Schraub DM, Simpson J, Lankford J, Dean DD, Cochran DL, Boyan BD (1995) Effect of titanium surface roughness on proliferation, differentiation, and protein synthesis of human osteoblast-like cells (MG63). J Biomed Mater Res 29: 389401 .

Matsuda T, Davies JE (1987) The in vitro response of osteoblasts to bioactive glass. Biomaterials 8: 275-284.

Oghushi H, Dohi Y, Yoshikawa T, Tamai T, Tabata S, Okunaga K, Shibuya T (1996) Osteogenic differentiation of cultured marrow stem cells on the surface of bioactive glass ceramic. J Biomed Mater Res 32: 341-348.

Oonishi H, Kushitani S, Yasukawa E, Iwaki H, Hench L, Wilson J, Tsuji E, Sugihara T (1997) Particulate bioglass compared with hydroxyapatite as a bone graft susbstitute. Clin Orthop Rel Res 334: 316-325.

Park JS, Suh JJ, Choi SH, Moon IS, Cho KS, Kim CK, Chai JK (2001) Effects of pretreatment clinical parameters on bioactive glass implantation in intra bony periodontal defects. J Periodontol 72: 730-740.

Price N, Bendall S, Frondoza C, Jinnah R, Hungerford D (1997) Human osteoblast-like cells (MG63) proliferate on bioactive glass surface. J Biomed Mater Res 37: 394400.

Reck R, Storkel S, Meyer A (1988) Bioactive glass ceramics in middle ear surgery. An 8 year review. Ann N Y Acad Sci 523: 100-106.

Radin S, Ducheyne P, Rothman B, Conti A (1997) The effect of in vitro modeling conditions on the surface reactions on bioactive glass. J Biomed Mater Res 37: 363375.

Ryoo HM, Hoffmann HM, Beumer T, Frenkel B, Towler DA, Stein GS, Stein JL, van Wijnen AJ, Lian JB (1997) Stage specific expression of Dlx5 during osteoblast differentiation: involvement in regulation of osteocalcin gene expression. Mol Endocrinol 11: 16811694.

Sasaki-Iwaoka H, Maruyama K, Endoh H, Komori T, Kato S, Kawashima H (1999) A trans-acting enhancer modulates estrogen-mediated transcription of reporter genes in osteoblasts. J Bone Miner Res 14: 248-255.

Virdi A, Cook L, Oreffo R, Triffitt J (1998) Modula- 
tion of bone morphogenetic protein-2 and bone morphogenetic protein-4 gene expression in osteoblastic cell lines. Cell Mol Biol 44: 1237-1246.

Vrouwenvelder WCA, Groot CG, Groot K (1992) Behavior of fetal rat osteoblasts cultured in vitro on bioactive glass and non reactive glasses. Biomaterials 13: 382-392.

Vrouwenvelder WCA, Groot CG, Groot K (1993) Histological and biochemical evaluation of osteoblasts cultured on bioactive glass, hydroxylapatite, titanium alloy, and stainless steel. J Biomed Mat Res 27: 465-475.

Vrouwenvelder WCA, Groot CG, Groot K (1994) Better histology and biochemistry for osteoblasts cultured on titanium doped bioactive glass: 45S5 compared with iron, titanium, fluoride and boron containing bioactive glasses. Biomaterials 15: 97-106.

Xynos ID, Hukkanen MV, Batten JJ, Buttery LD, Hench LL, Polak JM (2000) Bioglass 45S5 stimulates osteoblast turnover and enhances bone formation in vitro: implication and applications for bone tissue engineering. Calcif Tissue Int 67: 321-329.

Yukna RA, Evans GH, Aichelmann-Reidy MB, Mayer ET (2001) Clinical comparison of bioactive glass bone replacement graft material and expanded polytetrafluoroethylene barrier membrane in treating human mandibular molar class II furcations. J Periodontol 72: $125-133$.

\section{Discussion with Reviewers}

M.Alini: Semi-quantitative techniques of the mRNA analyses could lead to over-inerpretation of the results.

Authors: We agree with this and feel further confirmation of any possible positive effect should be established using more quantitative methods such as real time PCR or Northern Blot analysis.

D. Jones: Bioglass is mechanically totally unsuitable for large (or small) bone defects. Does it resorb? If not, what is its use? No case is made for the application.

Authors: While it is true that Bioglass ${ }^{\circledR}$ is not suitable for load bearing defects, the material has been commercially available for bone grafting of oral bony defects under the tradename PerioGlas ${ }^{\circledR}$ for nearly 10 years. It has been successfully sold in Germany for this use for 6 years.
The material has also been used to fill a variety of nonstructural bone voids in orthopaedics for 3 years, under the trade name NovaBone ${ }^{\circledR}$. It was not the intent of this article to make a case for clinical use, but rather to shed light on the possible mechanisms and interesting biochemical findings when bioactive glasses of different compositions are cultured in a widely used and accepted bone cell line.

D. Jones: Cells that attach to bone. Bone has only one layer of osteoblasts on the surface, and no three-dimensional (3D) connections are with osteocytes (none here) and marrow cells. What will happen almost certainly is that the mass of cells will grow, form cartilage, and then be invaded by blood vessels as the cells die. Blood vessels bring in other bone forming stem cells with vessels. The stuff will then probably after many months in the site then resorb because the biomechanics around the bioglass is not physiological.

Authors: It appears that the reviewer is making a point here, and the authors thank the reviewer for the comment. It is evident that it is an in vitro study has the classical inconveniences inherent to cultures. Naturally, the 3D structure of bone with marrow spaces cannot be reproduced in cell cultures. The aim of our study was not to reproduce what happens in vivo when bioglasses are implanted in a bony site (More than 100 articles were published, by others, on this subject describing in vivo animal or human studies). The goal of using such cell cultures, is to analyse certain specific points (e.g. cell adhesion, cell differentiation) which are very difficult to study in vivo.

D. Jones: MG63 cells are actually cloned from a human osteosarcoma, not moderately differentiated osteoblast-like cells. They are transformed phenotype, thus substrate independent growth, unsuitable for biomaterial work of the type described.

Authors: We believe that this is an opinion, but not a fact. The literature is replete with studies, published in reputable journals using the MG 63 cell line. However, the fact that this cell line did not express osteocalcin or alkaline phosphatase, even after stimulation by either Vitamin D or dexamethazone, can reasonably make us say that they have the phenotype of osteoprogenitor cells rather than mature osteoblasts. 